SPECIAL ARTICLE / ARTIGO ESPECIAL

\title{
Living conditions, seroprevalence and symptoms of COVID-19 in slums in the Metropolitan Region of Vitória (Espírito Santo)
}

\section{Condições de vida, soro prevalência e sintomas de COVID-19 em favelas na Região Metropolitana de Vitória (Espirito Santo)}

\author{
Ethel Leonor Noia Maciel,", (D), Pablo Medeiros Jabor"II (D), Laylla Ribeiro Macedo" (D), \\ Gilton Luiz Almadaiv (D), Raphael Lubiana Zanottiv (D), Crispim Cerutti Juniorv (D), \\ Cristiana Costa Gomes vi (D), Filomena Euridice Carvalho de Alencarv (D), Tania Reutervil (D), \\ Vera Lúcia Gomes de Andradeiv (D), Orlei Amaral Cardosoiv (D), \\ Nésio Fernandes de Medeiros JuniorlV (D), Whisllay Maciel Bastos ${ }^{\mathrm{VIII}}$ (D), \\ Marlon Neves Bertolanix (D), Leticia Tabachi Silva ${ }^{1 x}$ (D), Eliana Zandonade ${ }^{\mathrm{x}}$ (D)
}

\begin{abstract}
Objective: to estimate the prevalence of SARS-CoV-2 infection in residents of the Greater Vitória region living in subnormal and non-subnormal agglomerates, and to compare sociodemographic and clinical characteristics of total residents (infected and not infected with SARS-CoV-2) between them. Methods: Populationbased prevalence study conducted by serological testing in 2020, with a study unit in households in Greater Vitória, grouped into census tracts classified as sub-normal agglomerates and non-sub-normal agglomerates. The two groups were compared in terms of prevalence and associated factors. The significance level adopted was 5\%. Results: The prevalence found in the sub-normal clusters was $12.05 \%$ (95\%CI 9.59-14.50), and in the non-sub-normal clusters $10.23 \%(95 \%$ CI $7.97-12.50)$ this difference was not statistically significant $(\mathrm{p}=0.273)$. Comparing the sociodemographic characteristics, more people who declare themselves to be of mixed race were found in the sub-normal clusters, a higher percentage of illiterates and people with only elementary education, greater number of residents per household, longer stay in public transportation, sharing a bathroom with another household, fewer bedrooms per residence and higher frequency of irregular water supply when compared to non-sub-normal clusters $(\mathrm{p}<0.05)$. Conclusions: The epidemiological characteristics of subnormal clusters' residents show the social inequalities that can hinder control measures in a pandemic situation.
\end{abstract}

Keywords: Coronavirus infections. Prevalence. Housing. Demography.

'Biomedical Center, Department of Nursing, Universidade Federal do Espírito Santo - Vitória (ES), Brazil.

"Epidemiology Laboratory, Universidade Federal do Espírito Santo - Vitória (ES), Brazil.

IIIJones dos Santos Neves Institute - Vitória (ES), Brazil.

"vespírito Santo State Department of Health - Vitória (ES), Brazil.

vUniversidade Federal do Espírito Santo - Vitória (ES), Brazil

vPan-American Health Organization - Vitória (ES), Brazil.

v"Universitary hospital Cassiano Antonio de Moraes - Vitória (ES), Brazil.

ViliTocantins State Health Department - Palmas (TO), Brasil.

ix Jones dos Santos Neves Institute - Vitória (ES), Brazil.

${ }^{x}$ Center for Exact Sciences, Universidade Federal do Espírito Santo - Vitória (ES), Brazil.

Corresponding author: Ethel Leonor Noia Maciel. Avenida Marechal Campos, 1468, Maruípe, CEP: 29043-900, Vitória (ES), Brasil.

E-mail: ethel.maciel@gmail.com

Conflict of interests: nothing to declare - Financial support: The research was financed by the State Health Department of Espírito Santo (SESA-ES). 
RESUMO: Objetivo: Estimar prevalência de infecção pelo SARS-CoV-2 em residentes na região da Grande Vitória, moradores de aglomerados subnormais e não subnormais, e comparar características sociodemográficas e clínicas dos residentes totais (infectados e não infectados com o SARS-CoV-2), entre esses aglomerados. Métodos: Estudo de prevalência de base populacional, por meio de teste sorológico realizado em 2020, com unidade de estudo em domicílios da Grande Vitória, agrupados em setores censitários classificados como aglomerados subnormais e aglomerados não subnormais. Os dois grupos foram comparados quanto à prevalência e aos fatores associados. O nível de significância adotado foi de 5\%. Resultados: A prevalência encontrada em não aglomerados subnormais foi $12,05 \%$ (IC95\% 9,59-14,50) e no grupo aglomerados não subnormais foi 10,23\% (IC95\% 7,97-12,50), e essa diferença não foi estatisticamente significante $(\mathrm{p}=0,273)$. Comparando-se as características sociodemográficas, encontraram-se nos aglomerados subnormais mais pessoas que se autodeclaram da raça/cor parda, percentual maior de analfabetos e de pessoas apenas com ensino fundamental, maior número de moradores por domicílio, maior permanência em transporte coletivo, compartilhamento de banheiro com outro domicílio, menos dormitórios por residência e maior frequência de abastecimento irregular de água quando comparado aos aglomerados não subnormais $(\mathrm{p}<0,05)$. Conclusões: As características epidemiológicas dos moradores de aglomerados subnormais evidenciam as desigualdades sociais que podem dificultar as medidas de controle em uma situação de pandemia.

Palavras-chave: Covid-19. Prevalência. Habitação. Distribuição espacial da população.

\section{INTRODUCTION}

The new coronavirus, called SARS-CoV-2, which causes the COVID-19 disease, was discovered on December 31, 2019 when cases of pneumonia diagnosed in Wuhan, China, were being investigated. The disease spread rapidly around the world and was declared, on January 30, 2020, as a Public Health Emergency of International Concern (PHEIC) by the World Health Organization (WHO) ${ }^{1}$. On March 11 of the same year, the WHO declared a COVID-19 pandemic. On July 12, 2020, at a global level, the number of confirmed cases had already surpassed 12,552,765 and the number of deaths was at 561,6171.2. In Brazil, the first case was confirmed on February 26, 2020. As of July 12, 2020, 1,800,827 cases and 70,398 deaths had been registered ${ }^{3}$.

When it comes to communicable and contagious diseases involving droplets or aerosols, situations that allow greater physical proximity, like housings with reduced space or other socioeconomic vulnerability conditions, facilitate their spread ${ }^{4-8}$. For COVID-19, this airborne transmission, similar to other infectious diseases such as tuberculosis, leprosy, among others, is also possible through contact with surfaces contaminated by the virus ${ }^{9}$.

The Brazilian Institute of Geography and Statistics (IBGE), through geographic analysis, classifies territorial areas according to social, economic and environmental criteria, aggregating areas with similar characteristics. This classification includes subnormal agglomerates ("aglomerados subnormais", AGSN), which are forms of irregular occupation of land owned by others (public or private) for housing purposes in urban areas and, in general, characterized by an irregular urban pattern, lack of essential public services and location with 
restrictions on occupation. The AGSN can contribute to the dissemination of COVID-19, either because of its structural and urban characteristics, or because of the socioeconomic conditions of residents ${ }^{10}$. For this article, the use of the term AGSN was standardized due to its definition by the IBGE mentioned.

The AGSN are made up of people subject to greater exposure and vulnerability, with households whose predominant characteristics are high density of inhabitants, poor lighting and ventilation conditions, and limited access to sanitation conditions (potable water, sewage, garbage collection), which is also evidenced by the results of this serological survey. In Brazil, these irregular settlements are known by various names, such as slums, invasions, grottos, lowlands, communities, villages, irregular subdivisions, stilts, among others ${ }^{10}$.

Estimating the magnitude of the disease in population-based studies and producing health indicators that can guide more focused public policies according to the epidemiological situation is one of the missions of epidemiology. The analysis of greater social vulnerability and its possible consequences for health services in the context of COVID19 , considering the socioeconomic characteristics and epidemiological profile of the population, can contribute to the establishment of these public policies. This study, therefore, aimed to:

1. estimate the prevalence of infection by SARS-CoV-2 in residents of the Greater Vitória region, residents of AGSN and non-subnormal agglomerations ("aglomerados não subnormais", AGNSN);

2. compare sociodemographic and clinical characteristics of total residents (infected and not infected with SARS-CoV-2) between conglomerates.

\section{METHODS}

This is a cross-sectional population-based study on the prevalence of SARS-CoV-2 infection, carried out between June 22 and 26, 2020, with households in Greater Vitória as the study unit, grouped into census tracts classified as AGSN and AGNSN. Then, a comparative study between the two populations was made. The study design was based on the protocol proposed by the $\mathrm{WHO}^{11}$.

This study was carried out in the Metropolitan Region of Espírito Santo (ES), according to the division of the state into macro-regions. Samples were obtained in the cities of Grande Vitória with the largest urban populations: Vitória, Vila Velha, Serra and Cariacica.

Although these four municipalities occupy $2.4 \%$ of the state's geographical area due to population density, the AGSN in these municipalities represent $49.7 \%$ of the AGSN in the whole state of ES. According to the 2010 IBGE Census, the total population of these municipalities is 1,500,392, of which 151,550 live in AGSN and the rest in AGNSN ${ }^{12}$. The Metropolitan Region of Greater Vitória has AGSN inserted in the respective municipalities, forming areas contiguous to the AGNSN, and the entire region can be seen as a homogeneous area stratified only by AGSN and AGNSN. 
To calculate the prevalence samples, the populations defined by the 2010 IBGE Census were considered, with expected prevalence of infection by COVID-19 (estimated by previous stages of the household survey in $\mathrm{ES}^{13}$ ) of $13 \%$ (AGSN) and $9 \%$ (AGNSN), sampling errors of $2.5-2.1 \%$, respectively, and a significance level of 5\%. The minimum sizes were 692 individuals in AGSN and 714 in AGNSN. These sample sizes have a statistical power of $70 \%$ to compare the prevalence between AGSN and AGNSN and above $80 \%$ for other comparisons. A systematic sampling by households was adopted, using the census sectors as clusters ${ }^{13}$.

In each municipality, census tracts were drawn and divided into two groups: AGSN and AGNSN, proportional to the size of the population in these municipalities. The draw took place in census sectors with urban population, with less than 100 hectares of area and more than 200 households, according to IBGE data for the 2020 Census. A random selection of households was carried out in the sectors, being only one resident selected at random. Each sector had 40 households.

Only individuals aged over 2 years were included to answer the questionnaire and blood sample collection for antibody detection test against SARS-CoV-2. To answer the interview, the resident should be over 16 years old or supervised by a responsible person.

For ethical reasons, in households where the selected individual tested positive, as well as in households with a symptomatic resident, the test was offered to the residents. These results, however, were not computed in the prevalence study.

The interviewers were previously trained to perform the exam with a blood sample obtained by means of digital puncture. The test used was the rapid immunochromatographic test for detection of Celer brand IgM and IgG antibody, in the Point Of Care (POC) test category, recommended by the WHO and registered with the National Health Surveillance Agency (ANVISA) under protocol 80537410048 , with sensitivity of $86.4 \%$ and specificity of $97.63 \%$, according to the manufacturer's data.

In addition to testing positive for SARS-CoV-2, taken as the outcome variable of this study, the following information was collected about the participants, according to geographic area: gender (female and male), age group (up to 20 years old, 21-40 years, 41-60 years, 61-80 years and 81 years and over), self-declared race/skin color (white, brown, black, yellow and indigenous), respondent's education (illiterate, incomplete 1st-4th grade of elementary school, complete 4th grade of elementary school, incomplete 5th-8th grade of elementary school, complete elementary school, incomplete high school, complete high school, incomplete higher education and complete higher education), number of household members (1, 2, 3, 4 or more), education of the person with the highest level of education in the household (illiterate, elementary school, high school, incomplete higher education and higher education), time on public transport per day (no resident uses, less than 30 minutes, between 30-60 minutes, more than 60 minutes), often needs to use transport per week (no resident uses it, up to three times, four times or more), bathroom (does not have a bathroom, exclusive bathroom, bathroom shared with another household/family), bedrooms (does not have a bedroom, one bedroom, two or three bedrooms, four bedrooms or more), water supply (no access to potable water; irregular supply, access on some days 
of the week; regular supply, available all days of the week), comorbidities (hypertension, diabetes mellitus, asthma, cancer, kidney disease, heart disease, obesity and other comorbidities), went to the health unit (yes, no), signs and symptoms of COVID-19 15 days prior to the interview, with yes or no answers (cough, myalgia, fatigue, sore throat, anosmia, dyspnea, diarrhea, fever, tachycardia, abdominal pain, vomiting and other symptoms), and other unrelated symptoms.

Data were collected using an application developed specifically for the survey and recorded on smartphones provided by IBGE, with real-time transfer to the survey coordination center. These data formed a database analyzed statistically using the SPSS program, version 20.0. Frequency tables were made, and the prevalence for each group was estimated on a timely basis and by confidence interval. The two groups were compared in terms of prevalence and factors associated with COVID-19 in bivariate analyses (sociodemographic profile, COVID-19 positivity outcome, household characteristics, comorbidities and symptoms), using the $\chi^{2}$ association test. The significance level adopted was $5 \%$.

All individuals selected to participate in the survey were informed about the study objectives, risks and benefits, and each participant signed an Informed Consent Form, or an Informed Assent Form in the case of children. The material and information were only collected after the consent forms were signed. Cases with reactive or positive test results were notified to the city's Health Surveillance Department for the necessary measures. Appropriate biological safety measures were taken to ensure the health of field researchers who worked in the collection of data and biological material. The researchers were also evaluated with a rapid test to detect antibodies to SARS-CoV-2 before starting the field work, and the regional coordination was instructed to carry out the replacement of researchers in case of symptoms or a reagent test. The project was approved by the Research Ethics Committee of Universidade de Vila Velha, under opinion number 4.009,337.

\section{RESULTS}

A total of 1,447 households were visited, following the distribution proportional to the size of the population in the sample municipalities - Cariacica, 290 households $(20.0 \%)$, Serra, 519 households (35.9\%), Vila Velha, 406 households (28.1\%), and Vitória, 232 (16.0\%) households - and the stratification into cluster groups, 714 in AGSN and 733 in AGNSN.

In total, 161 people had reactive tests, being 86 among AGSN residents and 75 in other locations. The prevalence found in the slum group was $12.05 \%$ (95\%CI 9.59-14.50), while in the AGNSN group it was $10.23 \%(95 \%$ CI 7.97-12.50). It is noteworthy that the ratio between prevalence values was $17.8 \%(12.05 / 10.23=17.8 \%)$, which indicates an excess risk of $17.8 \%$ in the most vulnerable group, with no statistical difference between groups by the $\chi^{2}$ test.

In households of individuals with reactive tests $(n=161)$, the test to detect antibodies was offered to all contacts present, excluding children under two years of age and those who did not wanted to perform the test. 
When evaluating the results of reagent tests among contacts of selected individuals who had reagent tests in the AGSN group, at least one contact with a reagent test was found in $6.3 \%$ of the households, while in other sectors the percentage was $4.1 \%(\mathrm{p}=0.057)$.

Comparing the sociodemographic characteristics of people living in AGSN with those living in AGNSN, a higher percentage of people who declare themselves brown is seen in AGSN, while in the AGNSN, the highest percentage was self-declared white $(\mathrm{p}<0.001)$. There was also a higher percentage of illiterates and people with only elementary education in the group of residents in AGSN compared to the highest percentage of people with complete higher education in AGNSN ( $\mathrm{p}<0.001$ ), as shown in Table 1.

As for the characteristics of residents and their households, there was a higher number of residents per household ( $\mathrm{p}=0.012$ ), lower educational level of the resident with more years of education ( $p<0.001)$, longer stay in public transport $(p<0.001)$, bathroom shared with another household ( $p<0.001)$, fewer bedrooms per household $(p=0.002)$ and higher frequency of irregular water supply $(\mathrm{p}=0.009)$. These data are shown in Table 2 . Regarding comorbidities, there were no statistically significant differences between residents of different types of agglomerates, as shown in Table 3.

Regarding symptoms self-reported by residents who tested positive, cough $(\mathrm{p}=0.012)$, myalgia (muscle pain) $(p=0.001)$, fatigue $(p<0.001)$, anosmia (loss of taste and smell) $(p<0.001)$, fever $(p<0.001)$ and tachycardia $(p=0.022)$ were more common, but these symptoms were not perceived as a reason for seeking medical care $(\mathrm{p}=0.200)$ (Table 4$)$.

\section{DISCUSSION}

This was the first study that sought to assess the prevalence of individuals infected with SARS-CoV-2 in a population survey comparing AGSN and AGNSN groups. This approach by territorial cuts classified as AGSN per the 2010 Demographic Census ${ }^{12}$ can help studies that aim to understand the impacts of social inequalities on the emergence or worsening of diseases and point out public policies for social protection and control of the pandemic.

The study found a prevalence of $12.05 \%$ (95\%CI 9.59-14.50) of individuals infected by SARS-CoV-2 in the AGSN group and 10.23\% (95\%CI 7.97-12.50) in the AGNSN group. The frequency of at least one contact with a reactive test among the positive respondents in the AGSN group was $6.3 \%$, while in the other clusters the percentage was $4.1 \%$.

In the same period of the pandemic, Espírito Santo had 9.61\% (data not yet published) of prevalence of COVID-19 evaluated in four stages of the epidemiological survey. The municipalities of Greater Vitória, which concentrated most cases, had $11.51 \%$ of its population infected. In municipalities in the countryside, the prevalence rose from 3.12 to $4.35 \%{ }^{14}$.

Although there was no statistically significant difference between the prevalence of positive individuals when comparing both clusters (AGNSN and AGSN), sociodemographic characteristics such as housing conditions and self-reported symptoms of COVID-19 among positive individuals showed that residents in the AGSN are in greater social vulnerability, 
Table 1. Frequency of variables of the sociodemographic profile per total, and subnormal and non-subnormal clusters groups.

\begin{tabular}{|c|c|c|c|c|c|c|c|c|}
\hline & \multirow{3}{*}{ Category } & \multicolumn{7}{|c|}{ Group } \\
\hline & & \multicolumn{2}{|c|}{ Total } & \multicolumn{2}{|c|}{ AGSN } & \multicolumn{2}{|c|}{ AGNSN } & \multirow{2}{*}{$\mathrm{p}$-value } \\
\hline & & $\mathrm{n}$ & $\%$ & $n$ & $\%$ & $\mathrm{n}$ & $\%$ & \\
\hline \multirow{2}{*}{ Gender } & Female & 940 & 65.0 & 465 & 65.1 & 475 & 64.8 & \multirow{2}{*}{0.897} \\
\hline & Male & 507 & 35.0 & 249 & 34.9 & 258 & 35.2 & \\
\hline \multirow{5}{*}{$\begin{array}{l}\text { Age } \\
\text { (years) }\end{array}$} & up to 20 & 84 & 5.8 & 35 & 4.9 & 49 & 6.7 & \multirow{5}{*}{0.307} \\
\hline & $21-40$ & 463 & 32.0 & 240 & 33.6 & 223 & 30.4 & \\
\hline & $41-60$ & 525 & 36.3 & 262 & 36.7 & 263 & 35.9 & \\
\hline & $61-80$ & 335 & 23.2 & 161 & 22.5 & 174 & 23.7 & \\
\hline & 81 & 40 & 2.8 & 16 & 2.2 & 24 & 3.3 & \\
\hline \multirow{5}{*}{$\begin{array}{l}\text { Race, skin } \\
\text { color }\end{array}$} & White & 515 & 35.6 & 217 & 30.4 & 298 & 40.7 & \multirow{5}{*}{0.001} \\
\hline & Borwn & 727 & 50.2 & 405 & 56.7 & 322 & 43.9 & \\
\hline & Black & 193 & 13.3 & 84 & 11.8 & 109 & 14.9 & \\
\hline & Yellow & 11 & 0.8 & 7 & 1.0 & 4 & 0.5 & \\
\hline & Indigenous & 1 & 0.1 & 1 & 0.1 & 0 & 0.0 & \\
\hline \multirow{9}{*}{ Education } & Illiterate & 44 & 3.1 & 34 & 4.8 & 10 & 1.4 & \multirow{9}{*}{0.001} \\
\hline & $\begin{array}{l}\text { Incomplete 1st-4th } \\
\text { grade of elementary } \\
\text { school }\end{array}$ & 163 & 11.3 & 105 & 14.8 & 58 & 8.0 & \\
\hline & $\begin{array}{l}\text { 4th grade of } \\
\text { elementary school }\end{array}$ & 76 & 5.3 & 52 & 7.3 & 24 & 3.3 & \\
\hline & $\begin{array}{l}\text { incomplete } 5 \text { th-8th } \\
\text { grade of elementary } \\
\text { school }\end{array}$ & 161 & 11.2 & 95 & 13.4 & 66 & 9.1 & \\
\hline & $\begin{array}{c}\text { Complete } \\
\text { elementary school }\end{array}$ & 121 & 8.4 & 70 & 9.8 & 51 & 7.0 & \\
\hline & $\begin{array}{l}\text { Incomplete high } \\
\text { school }\end{array}$ & 97 & 6.7 & 66 & 9.3 & 31 & 4.3 & \\
\hline & $\begin{array}{l}\text { Complete high } \\
\text { school }\end{array}$ & 507 & 35.3 & 224 & 31.5 & 283 & 38.9 & \\
\hline & $\begin{array}{l}\text { Incomplete higher } \\
\text { education }\end{array}$ & 62 & 4.3 & 21 & 3.0 & 41 & 5.6 & \\
\hline & $\begin{array}{l}\text { Complete higher } \\
\text { education }\end{array}$ & 207 & 14.4 & 44 & 6.2 & 163 & 22.4 & \\
\hline
\end{tabular}

AGSN: subnormal clusters; AGNSN: non-subnormal clusters. p-value of the $\chi^{2}$ test. 
Table 2. Frequency of household profile variables per total, subnormal and non-subnormal clusters.

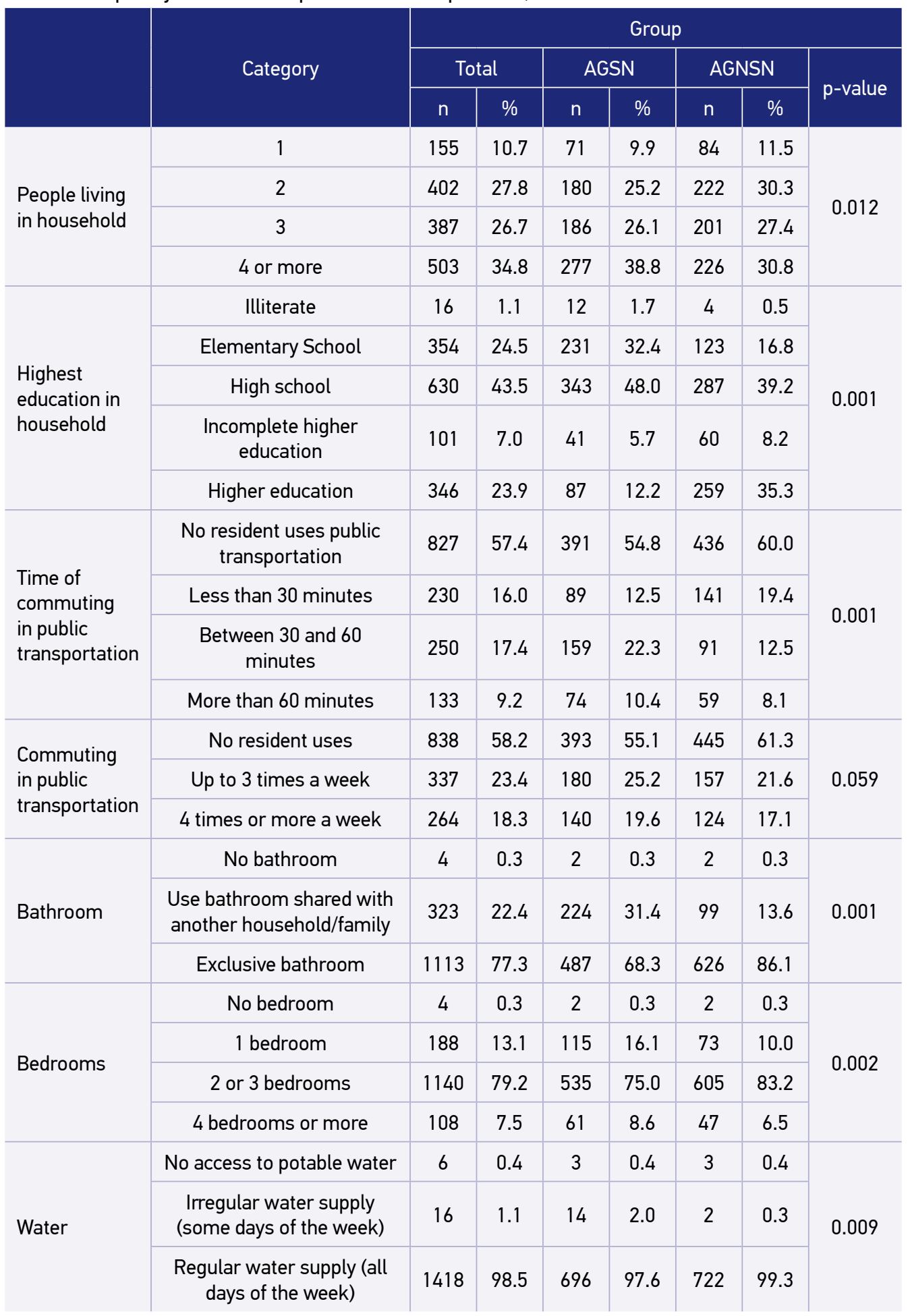

AGSN: subnormal clusters; AGNSN: non-subnormal clusters. $p$-value of the $\chi^{2}$ test. 
Table 3. Frequency of comorbidities of respondents per total, subnormal clusters and nonsubnormal clusters.

\begin{tabular}{l|c|c|c|c|c|c|c|}
\hline & \multicolumn{7}{c|}{ Group } \\
\cline { 2 - 7 } & \multicolumn{2}{|c|}{ Total } & \multicolumn{2}{c|}{ AGSN } & \multicolumn{2}{c}{ AGNSN } & p-value \\
\cline { 2 - 8 } & $\mathrm{n}$ & $\%$ & $\mathrm{n}$ & $\%$ & $\mathrm{n}$ & $\%$ & \\
\hline Arterial hypertension & 478 & 33.0 & 234 & 32.8 & 244 & 33.3 & 0.835 \\
\hline Diabetes mellitus & 195 & 13.5 & 95 & 13.3 & 100 & 13.6 & 0.851 \\
\hline Asthma & 120 & 8.3 & 53 & 7.4 & 67 & 9.1 & 0.236 \\
\hline Neoplasm & 23 & 1.6 & 8 & 1.1 & 15 & 2.0 & 0.159 \\
\hline Kidney disease & 25 & 1.7 & 9 & 1.3 & 16 & 2.2 & 0.178 \\
\hline Cardiovascular disease & 86 & 5.9 & 43 & 6.0 & 43 & 5.9 & 0.900 \\
\hline Obesity & 196 & 13.5 & 101 & 14.1 & 95 & 13.0 & 0.510 \\
\hline Other comorbidities & 118 & 8.2 & 55 & 7.7 & 63 & 8.6 & 0.535 \\
\hline
\end{tabular}

AGSN: subnormal clusters; AGNSN: non-subnormal clusters. p-value of the $\chi^{2}$ test.

Table 4. Variables of symptoms and search for health unit per total number of respondents, subnormal clusters and non-subnormal clusters, from the highest frequency.

\begin{tabular}{|c|c|c|c|c|c|c|c|}
\hline & & & & Group & & & \\
\hline & & & & & & & \\
\hline & $\mathrm{n}$ & $\%$ & $\mathrm{n}$ & $\%$ & $\mathrm{n}$ & $\%$ & \\
\hline Cough & 234 & 16.2 & 133 & 18.6 & 101 & 13.8 & 0.012 \\
\hline Myalgia & 192 & 13.3 & 116 & 16.2 & 76 & 10.4 & 0.001 \\
\hline Fatigue & 163 & 11.3 & 103 & 14.4 & 60 & 8.2 & 0.001 \\
\hline Sore throat & 159 & 11.0 & 73 & 10.2 & 86 & 11.7 & 0.359 \\
\hline Anosmia & 137 & 9.5 & 86 & 12.0 & 51 & 7.0 & 0.001 \\
\hline Dyspnea & 133 & 9.2 & 72 & 10.1 & 61 & 8.3 & 0.246 \\
\hline Diarrhea & 111 & 7.7 & 55 & 7.7 & 56 & 7.6 & 0.964 \\
\hline Other symptoms & 109 & 7.5 & 58 & 8.1 & 51 & 7.0 & 0.705 \\
\hline Fever & 104 & 7.2 & 66 & 9.2 & 38 & 5.2 & 0.003 \\
\hline Tachycardia & 92 & 6.4 & 56 & 7.8 & 36 & 4.9 & 0.022 \\
\hline Abdominal pain & 87 & 6.0 & 46 & 6.4 & 41 & 5.6 & 0.497 \\
\hline Vomiting & 31 & 2.1 & 17 & 2.4 & 14 & 1.9 & 0.536 \\
\hline Went to the HU & 260 & 18.0 & 119 & 16.7 & 141 & 19.2 & 0.203 \\
\hline
\end{tabular}

HU: health unit; AGSN: subnormal clusters; AGNSN: non-subnormal clusters. p-value of the $\chi^{2}$ test. 
which could increase exposure to the disease within the household, as warned in studies by the IBGE ${ }^{10}$.

In Espírito Santo, $14.37 \%$ of the population does not have access to water through the general distribution network, $21.83 \%$ do not have access to sewage through the collection or rainwater system, $8.73 \%$ do not have access to direct or indirect garbage collection, and $23.47 \%$ do not have simultaneous access to the three sanitation services ${ }^{15}$. Regarding housing conditions, there are 13,136 people living in precarious situation and 6,295 living in households with excessive density ${ }^{12}$.

Recent data from IBGE (2019) were released prior to the 2020 Census to assist in the performance of the government in confronting COVID-19. The data show that Espírito Santo is one of the states with the highest number of households in AGSN, ranking second, with $26.10 \%$. This corresponds to 306,439 households, lower only than in Amazonas, where the value is $34.59 \%$. In the state capital, Vitória, there are 34,393 households in AGSN, which represent $33.15 \%$ of all in the municipality. By definition, the AGSN generally hold populations with more precarious socioeconomic, sanitation and housing conditions. As an aggravating factor, many AGSN have an extremely high density of buildings ${ }^{10}$.

Although infected AGSN residents reported having more symptoms, this situation did not lead them to seek health services, for reasons that it was not possible to identify given the methodology and objectives of this study. However, data from the National Household Sample Survey (PNAD) have shown that, despite their need for health care, individuals with lower purchasing power tend to consume less these services ${ }^{15,16}$.

Adequate living and mobility conditions help not only the prevention of chronic-degenerative diseases and the promotion of well-being, but also the control of infectious diseases such as dengue, chikungunya, zika and, currently, COVID-19 $9^{5-8,17,18}$. Studies that analyzed the characteristics of these AGSN in other infectious diseases showed their association with social inequality, poverty and precarious living conditions $s^{17-22}$. The geographic distribution combined with low education, social inequality and migratory movements are also pointed as determining factors of illness ${ }^{23,24}$. However, our results did not find a statistically significant difference between the prevalence of reactive tests in the two types of clusters, despite the statistical differences in the housing conditions and transport habits of the residents, it is possible that, at the time of this survey, the situation of COVID-19 transmission among residents of the areas assessed had a similar behavior, which could be related to the place of work and leisure and mobility conditions in the Greater Vitória region. However, variables related to the place of work and leisure activities were not included in the questionnaire of this survey.

One of the limitations of this study was its cross-sectional design, which does not allow the determination of causality. Carrying out the household survey during business hours and on weekdays could influence the result, since only the residents present in the household at the time of data collection entered the draw to answer the questionnaire and to be tested for antibodies. Furthermore, transmission could be in different moments in the 
two populations. Also regarding the design, it is important to say that, as in other randomized population-based studies, people with severe disease or who required hospitalization were not present to be computed in the prevalence. During the study, the state of Espírito Santo had no problems in admitting patients to both public and private health services. It is assumed that this limitation affected both studied groups equally ${ }^{25}$.

Important to note that the results of the reagent tests among the contacts of selected individuals who had reagent tests in the AGSN group was higher, which could indicate that housing conditions, like in other infectious diseases, influence household transmission ${ }^{7,8}$.

Bezerra et al. ${ }^{26}$, evaluating factors associated with the behavior of the population during the pandemic in Brazil, showed that people who reported living in worse housing conditions were willing to spend less time in isolation (73.9\%). Among people who were not isolated $(10.7 \%$ of the total), $75.8 \%$ said they believed that social isolation would reduce the number of victims of COVID-19. The authors concluded that people's perception of social isolation as a measure to mitigate the pandemic varies according to income, education, age and gender ${ }^{26}$.

A study evaluating the disparity in subway use and the outcome of COVID-19 in New York pointed to inequalities as factors that increase vulnerability to the disease ${ }^{27}$. Areas with a lower median income and a higher percentage of self-declared non-white individuals had a higher percentage of essential workers and a higher percentage of health professionals who used more subways during the pandemic. In poorer neighborhoods, greater mobility of the population in relation to the richer ones was seen, which increases vulnerability to COVID-1927. Although the theoretical foundation about areas with lower median income in other countries indicates a direction, in this study this variable was not measured, setting up a limitation.

Another study conducted in the United States using the postal code as the unit of analysis showed that, despite race being used as a proxy variable for socioeconomic status, the most significant predictor of a COVID-19 positive case was an individual's structural environment, that is, population density in their place of residence ${ }^{28}$.

Old issues are highlighted at this time of pandemic, such as sanitation, household density, precarious housing and mobility. The city was historically formed in segregated spaces between those who could afford it and those who improvised ways of living, occupying spaces without infrastructure and environmentally fragile. This formation of cities without concern for social inequality brings problems that have been increasingly recurrent and larger, such as floods, droughts and the spread of diseases. This inequality increases daily, and the COVID-19 pandemic shows us how this discrepancy is harmful to everyone, even those who live in adequate conditions and have access to sanitation ${ }^{27-29}$.

Finally, as the household is not only the smallest spatial unit where the process of transmission of infectious agents takes place, but also a fundamental unit in the study of social reproduction ${ }^{30}$, in which the cultural and economic relations of groups in their collectivity materialize, actions that can disproportionately reduce severe cases should be prioritized in government public policies aimed at the socially vulnerable. 


\section{REFERENCES}

1. World Health Organization. IHR procedures concerning public health emergencies of international concern (PHEIC). Geneva: World Health Organization; 2005 [accessed on Jul 28, 2021]. Available at: http: / / www. who.int/ihr/procedures/pheic/en/

2. World Health Organization. Coronavirus disease (COVID-19) Pandemic. Geneva: World Health Organization; 2019. [accessed on Jun 28, 2020]. Available at: https: / / www.who.int/emergencies/diseases / novel-coronavirus-2019

3. World Health Organization. WHO Coronavirus Disease (COVID-19) Dashboard. Geneva: World Health Organization; 2020. [accessed on Jun 28, 2020]. Available at: https: / covid19.who.int/

4. Snyder RE, Marlow MA, Phuphanich ME, Riley LW, Maciel ELN. Risk factors for differential outcome following directly observed treatment (DOT) of slum and non-slum tuberculosis patients: a retrospective cohort study. BMC Infect Dis 2016; 16: 494. https: / / doi.org/10.1186/s12879-016-1835-1

5. Mocelin HJS, Catão RC, Freitas PSS, Prado TN, Bertolde AI, Castro MC, et al. Analysis of the spatial distribution of cases of Zika virus infection and congenital Zika virus syndrome in a state in the southeastern region of Brazil: Sociodemographic factors and implications for public health. Int J Gynaecol Obstet 2020;148 (Suppl 2): 61-9. https:// doi.org/10.1002/ijgo.13049

6. Gomes MGM, Oliveira JF, Bertolde A, Ayabina D, Nguyen TA, Maciel EL et al. Introducing risk inequality metrics in tuberculosis policy development. Nat Commun 2019; 10 (1): 2480. https:// doi.org/10.1038/s41467-019-10447-y

7. Honorato T, Lapa PP, Sales CM, Reis-Santos B, Tristão-Sá $\mathrm{R}$, Bertolde AI et al. Spatial analysis of distribution of dengue cases in Espírito Santo, Brazil, in 2010: use of Bayesian model. Rev Bras Epidemiol 2014; 17 (Suppl 2): 150-9. https: / / doi.org/10.1590/1809-4503201400060013

8. Sampaio PB, Bertolde AI, Maciel EL, Zandonade E. Spatial distribution of leprosy in Brazil: a literature review [Internet]. Rev Soc Bras Med Trop 2017; 50 (4): 439-49. https: / / doi.org/10.1590/0037-8682-0170-2016

. Brasil. Secretaria de Vigilância em Saúde. Ministério da Saúde. Infecção humana pelo novo coronavírus (2019-nCoV). 2021[accessed on Jul 28, 2021]. Available at: https: / / coronavirus.saude.gov.br/

10. Instituto Brasileiro de Geografia e Estatistica. Nota Técnica 01 / 2020: Aglomerados Subnormais 2019: Classificação preliminar e informações de saúde para o enfrentamento à COVID-19. Rio de Janeiro; 2020 [accessed on Jul 28, 2021]. Available at: https://biblioteca.ibge.gov.br/ visualizacao/livros/liv101717_notas_tecnicas.pdf
11. World Health Organization. Population-based age-stratified seroepidemiological investigation protocol for COVID-19 virus infection, 17 March 2020. Geneva: World Health Organization; 2020 [accessed on Jul 28, 2021]. Available at: https:// apps.who.int/iris/bitstream/handle/10665/331656/ WHO-2019-nCoV-Seroepidemiology-2020.1-eng. pdf? sequence $=1$ \&isAllowed $=\mathrm{y}$

12. Instituto Brasileiro de Geografia e Estatistica. Censo Brasileiro de 2010. Rio de Janeiro: IBGE; 2012 [accessed on Jul 28, 2021]. Available at: https:// censo2010.ibge.gov.br/

13. Gomes CC, Cerutti C, Zandonade E, Maciel ELN, Alencar FEC, Almada GL, et al. A population-based study of the prevalence of COVID-19 infection in Espirito Santo, Brazil: methodology and results of the first stage. medRxiv 2020. https:// doi. org/10.1101/2020.06.13.20130559

14. Universidade Federal do Espírito Santo. Quarta etapa do inquérito epidemiológico no ES indica aumento do contágio pelo novo coronavírus. 2020 [accessed on Jul 28, 2021]. Available at: https:// www.ufes.br/conteudo/quarta-etapa-do-inqueritoepidemiologico-no-es-indica-aumento-do-contagiopelo-novo

15. Neri M, Soares W. Desigualdade social e saúde no Brasil. Cad Saúde Pública 2002; 18 (Suppl): S77-87. https://doi.org/10.1590/ S0102-311X2002000700009

16. Lima-Costa MF, Barreto S, Giatti L, Uchôa E. Desigualdade social e saúde entre idosos brasileiros: um estudo baseado na Pesquisa Nacional por Amostra de Domicílios. Cad Saúde Pública 2003; 19 (3): 745-57. https://doi.org/10.1590/ S0102-311X2003000300007

17. Marlow MA, Maciel EL, Sales CM, Gomes T, Snyder RE, Daumas RP, et al. Tuberculosis DALY-Gap: spatial and quantitative comparison of disease burden across urban slum and non-slum census tracts. J Urban Health 2015; 92 (4): 622-34. https: / / doi.org/10.1007/ s11524-015-9957-0

18. Maciel EL, ReisSantos B. Determinants of tuberculosis in Brazil: from conceptual framework to practical application. Rev Panam Salud Publica 2015; 38: 28-34.5. PMID: 26506318

19. Lönnroth K, Jaramillo E, Williams BG, Dye C, Raviglione M. Drivers of tuberculosis epidemics: the role of risk factors and social determinants. Soc Sci Med 2009; 68 (12): 2240-6. https: / / doi.org/10.1016/j. socscimed.2009.03.041 
20. Dye C, Lönnroth K, Jaramillo E, Williams BG, Raviglione $\mathrm{M}$. Trends in tuberculosis incidence and their determinants in 134 countries. Bull World Health Organ 2009; 87 (9): 683-91. https: / / doi.org/10.2471/blt.08.058453

21. Anderson G, Frank JW, Naylor CD, Wodchis W, Freng P. Using socioeconomics to counter health disparities arising from the COVID-19 pandemic. BMJ 2020; 369 : m2149. https:// doi.org/10.1136/bmj.m2149

22. Chowkwanyun M, Reed Junior AL. Racial health disparities and COVID-19 - caution and context. N Engl J Med 2020; 383 (3): 201-3. https: / / doi.org/10.1056/ NEJMp2012910

23. Magalhães MCC, Rojas LI. Diferenciação territorial da hanseníase no Brasil. Epidemiol Serv Saúde 2007; 16 (2): 75-84. http://doi.org/10.5123/ S1679-49742007000200002

24. Andrade VLGS, Sabroza PC, Araújo AJG. Fatores associados ao domicílio e à família na determinação da hanseníase. Cad Saúde Pública 1994; 10 (Suppl 2): S28192. https: / / doi.org/10.1590/S0102-311X1994000800006

25. Maciel EL, Jabor P, Goncalves Júnior E, Tristão-Sá R, Lima RCD, Reis-Santos B, et al. Factors associated with COVID-19 hospital deaths in Espírito Santo, Brazil, 2020. Epidemiol Serv Saúde 2020; 29 (4): e2020413. https: / / doi.org/10.1590/S1679-49742020000400022

26. Bezerra ACV, Silva CEM, Soares FRG, Silva JAM. Fatores associados ao comportamento da população durante o isolamento social na pandemia de COVID19. Ciênc Saúde Coletiva 2020; 25 (Suppl 1): 2411-21. https: / doi.org/10.1590/1413-81232020256.1.10792020

27. Sy KTL, Martinez ME, Rader B, White LF. Socioeconomic disparities in subway use and COVID-19 outcomes in New York City. medRxiv 2020: 2020.05.28.20115949. https: / / doi.org/10.1101/2020.05.28.20115949
28. Guha A, Bonsu J, Dey A, Addison D. Community and Socioeconomic Factors Associated with COVID-19 in the United States: Zip code level cross sectional analysis. medRxiv 2020: 2020.04.19.20071944. https: / / doi.org/10.1101/2020.04.19.20071944

29. Silva LT. A Produção de localizações: estruturação territorial da Grande Vitória [Masters dissertation]. São Paulo: Faculdade de arquitetura e urbanismo; 2014.

30. Breilh J. Principios generales para um nuevo tipo de método en la investigation epidemiológica. In: Epidemiologia economia, medicina y política. México: Editorial Premia;1988. p. 177-91

Received on: 06/17/2021

Revised on: 07/30/2021

Accepted on: 08/05/2021

Preprint on: 06/10/2021

(https://doi.org/10.1590/SciELOPreprints.2446)

Author's contributions: ELNM: conceptualization, data curation, formal analysis, writing - original draft, writing - review \& editing. PMJ: writing - review $\&$ editing. LRM: writing - review \& editing. GLA: writing - review \& editing. RLZ: writing - review \& editing. CCJ: writing - review \& editing. CCG: writing - review \& editing. FECA: writing - review \& editing. TR: writing - review \& editing. VLGA: writing - review \& editing OAC: writing - review \& editing. NFMJ: writing - review \& editing. WMB: writing - review \& editing. MNB: writing - review \& editing. LTS: writing - review \& editing. EZ: conceptualization, data curation, formal analysis, writing - original draft, writing - review \& editing. 